\title{
CONSERVATIVE ACTIONS : A COMPARISON OF THE INVASIONS OF VIETNAM AND AFGHANISTAN
}

\author{
by Lawrence A. Howard
}

I.

Westerners-when they give attention to the bitter struggle raging in Afghanistan-commonly characterize it as "Russia's Vietnam." The characterization carries with it some misleading intellectual baggage, stuff damaged in transit during America's defeat in Vietnam : the thesis that the use of military force in the Third World by a superpower inevitably runs counter to its own interests. Currently the apparent stalemate between Soviet forces and the mujahedeen offers the most convincing proof for this thesis: however, soothsayers run high risks of error by basing their predictions of Soviet failure on American defeat. ${ }^{2}$

The key to understanding the fallacy of thinking that Afghanistan is Russia's Vietnam lies in understanding the traditional political cultures of Vietnam and Afghanistan. The parallels and contrasts that exist between the two invasions both strongly suggest that military force can be successfully used in conjunction with a correct understanding of the local political culture. The Soviets understand the cultural context of Afghanistan better than the Americans understood the culture of Vietnam and because Soviet

1 William K. Stevens, "Afghanistan Isn't Quite Russia's Vietnam-or Russia's Afghanistan: Whose Side is Time on This Time?" The New York Times, October 3, 1982, p. E2.

2 One review of the world's press prior to the British success in the Falklands showed a similar error in prediction. There was an almost universally pessimistic outlook for the British. See "The World Looks at the Falklands," World Press Review, May 1982, p. 20. 
policy is culturally appropriate to their battleground there is a good chance that Soviet forces will prevail in Afghanis$\tan$.

Neither the invasion of Vietnam nor the invasion of Afghanistan immediately threatened to destroy the precarious global balance of power. Ultimate Soviet victory in Afghanistan poses such a threat and it is therefore imperative that the United States-and other Western powers-understand and deal with the danger of a Soviet victory over the mujahedeen.

II.

The United States in Vietnam and the USSR in Afghanistan had four similar motivations for invasion:

(1) Each superpower had long-range ideological motivations;

(2) Each had long-standing geopolitical motivations;

(3) Each had immediate political/ideological concerns;

(4) Each perceived that a successful invasion was permitted by a favorable correlation of forces.

The long-range ideological motivations that halped draw the United States into Vietnam coalesced in the generalization of "Containment" from Europe to the world. Democracy vs communism. It is general wisdom that the French pleas for American support of its colonial war in Indochina would not have drawn the magnanimous levels of material and finance that they did if those pleas had not been couched in the ideological rhetoric of the Cold War. ${ }^{3}$ France made the good fight for all of the West (especially 1950-1955) against the communist barbarians in Indochina.

Similarly the Soviet Union perceives that it is hastening the inevitable demise of the capitalist West by helping Marxism-Leninism triumph in Afghanistan. The December

${ }^{3}$ Michael Maclear, The Ten Thousand Day War (New York: St. Martin's, 1981), p. 27. 
1979 invasion is often thought of by Americans as the Soviet perfidity whcih hammered the nails in the coffin of Detente. In the Soviet Union the invasion carried no such significance. Detente, like "Peaceful Coexistence" before it, never denoted the end of the ideological struggle with the West. ${ }^{4}$ The support of fraternal parties and national liberation movements is merely a continuation of the ideological struggle-especially valid in areas of the world where there is little risk of a direct physical confrontation with the United States.

The geopolitical motivation of the United States inVietnam grew out of its position as a Pacific power. When it took the former Mandated islands from Japan during World War II it merely added more territory to the American perimeter in the Far East. The Cold War prompted forward movement of the new perimeter-just as tensions on borders in the past have prompted great powers to advance forward in hope of securing a more defensible line. The British advances throughout India and into Assam and Afghanistan are a classic example of what the United States did-in a different manner-throughout the Far East. ${ }^{5}$ The geopolitical impetus reinforced the ideological impetus in a relationship of mutual succor. Indochina was perceived as a front-line staging area for the containment of the Soviet Union and China. The loss of Indochina would force the United States back to a secondary line of defense in the Pacific Islands. ${ }^{6}$ The rationale of SEATO was to link NATO

4 John Lenzowski, Soviet Perceptions of U.S. Foreign Policy (New York: Cornell University Press, 1982), pp. 37-51.

5 As an historical note one could trace the competition between the United States and the USSR back to the middle of the 19th Century when the United States and Russia competed for influence in China. I am indebted to Professor Oral Sander, University of Ankara, Turkey, for his observations on this subject. The Cold War is seen by Professor Sander as an advenced stage of border confrontation between two "continental powers."

6 For an example of official thinking on how the United States has been pushed back to a secondary line of defense in the Pacific Islands read former Secretary of Defense Robert Ellsworth, "U.S. Defense Interests in the Northern Marianas," Commanders Digest, January 22, 1976, pp. 3-7. 
with the Far East through CENTO and ring the communist world. All countries in the "ring" were the front line of defense for the West.

The Soviet geopolitical motivations are likewise in mutual succor with their long-range ideological motivations. Much is made of the traditional thrust, continued by the Soviet regime, for a warm water port. It so happens that a Soviet port on the Indian Ocean would mean the liquidation of Pakistan as both an American and a Chinese ally. It would increase the pressure on India and give darker meaning to the Indo-Soviet Friendship Treaty. ${ }^{7}$ It would increase pressure on Iran and put Soviet naval forces in a commanding strategic position over the Persian Gulf, Saudi Arabia, East Africa, and Turkey. ${ }^{8}$ The capitalist encirclement of the Soviet Union would be a thing of the past and the inevitable triumph of Marxism-Leninism would be far closer.

The immediate political/ideological concerns of the United States in Vietnam were formally capsulized in the Domino Theory. If Vietnam fell then so would Laos, Cambodia, Thailand, India, etc. A bad precedent for Containment.

Similarly the Soviet Union capsulizes its own immedate concerns in the form of the Brezhnev Doctrine. ${ }^{9}$ When a state becomes a part of the socialist camp it is entitled to help from the leading socialist state to protect it from reactionary forces of counterrevolution. Counterrevolution would be unnecessarily encouraged if the Soviet Union

${ }^{7}$ C.M. Samuel, India Treaty Manual (Mysore: Wesley Press, 1972), pp. 287. For complete indexing and analyses of Indian and Soviet treaties see Peter H. Rohn, World Treaty Index (Santa Barbara: ABC Clio, 2nd edition forthcoming). This new edition includes Rohn's Treaty Profiles (first published by Clio in 1976).

${ }^{8}$ Oral Sander informs me that the Turkish government, although extremely cautious about condemning Soviet actions in the recent past, has openly and strongly condemned the invasion of Afghanistan.

${ }^{9}$ Sergei Kovalev, "Sovereignty and the International Duties of Socialist Countries," Pravda, September 26, 1968. Reprinted in Alvin Z Rubinstein, The Foreign Policy of the Soviet Union (New York: Random House, 1972), pp. 302-305. 
allowed Afghanistan, a socialist state bordering on the Soviet Union, to backslide into reaction.

None of these motivations alone would have been impetus enough for the invasions of Vietnam and Afghanistan. What made them critical was their combination with a perception of a favorable opportunity to invade-or as the Soviets perceived it, a favorable "correlation of forces." Not only did each superpower see good reason to make its invasion it saw no danger of significant opposition from the other.

President Johnson sent in the marines in 1965 only a little over 2 years after the October 1962 showdown in Cuba between Kennedy and Khrushchev proved to the United States, for the moment, that there were one-and-a-half superpowers in the world. American policy makers did not think it likely that the Soviet Union would risk a direct confrontation in Vietnam and indeed the Soviets did not. There was fear of a Chinese response but the lesson drawn from the Korean War was clear: if Chinese borders were not threatened nor the existence of North Vietnam threatened then the United States would have to contend only with the NLF and North Vietnamese regulars.

For the Soviet Union the fall of the Shah-in whom the United States had invested so much-showed that the United States was neither able to control events in Central Asia nor respond effectively to challenges there. This analysis was confirmed for the Soviets midway through their August-December 1979 preparations for the invasion of Afghanistan by the seizure of the American embassy hostages in Tehran. In December the Soviets made their invasion after receiving repeated warnings from the Carter Administration that there would be dire consequences if Soviet troops crossed the border. ${ }^{10}$ American logistics were terrible in Afghanistan and American credibility lowa situ-

10 Jimmy Carter, Keeping Faith: Memoirs of a President (New York: Bantam Books, 1982), pp. 471-472. See also Anthony Arnold, Afghanistan, the Soviet Invasion in Perspective (Stanford: Hoover Institution, 1981). p. 103. 
ation parallel to that of the Soviets in Cuba in 1962. The dire consequences threatened by President Carter revealed themselves as draft registration, a boycott of the Olympics, and weak technology and grain embargoes.

There is a major contrast in addition to the parallels drawn so far. The Soviet Union wanted to forestall the penetration of Islamic fundamentalism into its Central Asian republics. The United States had no comparable motivation in sending troops to a non-contiguous backwater half-way around the world. A comparable motivation would have existed if a highly popular, hostile ideology had arisen in Mexico and threatened to infect Hispanic Americans in California, Arizona, New Mexico, and Texas. The Soviet Union can be accused of looking at Iran, Afghanistan, and Pakistan as natural geographic and ethnic extensions of its Central Asian republics. But the reverse is also true-and the Soviets are not blind to the possibilities: the view from Tehran or Kabul can be that Soviet Central Asia is a natural extension of non-Soviet Central Asia. ${ }^{11}$ Moscow finds it difficult enough to live with Ayatollah Khomeini. A spirit kindred to Khomeini in Kabul-one who had overthrown a Marxist regime-would be intolerable.

III.

The invasions of Vietnam and Afghanistan occurred because of what Waltz describes as the "simplicity" of relations within the essentially bipolar system that characterizes superpower politics. ${ }^{2}$ The correlation of forces is an easier thing to discern when you know exactly who your enemy is. But knowing your enemy does not mean that you are safe from misperceiving your own interests.

There were no major American interests in Vietnam strategic or otherwise. There had once been an economic interest in the form of rubber but the Japanese forced the

${ }^{11}$ Eden Naby, "The Ethnic Factor in Soviet-Afghan Relations," Asian Survey, March 1980, pp. 252-253.

12 Kenneth N. Waltz, Theory of International Politics (Reading. Addison-Wesley, 1979), pp. 170-176. 
Americans to invent synthetic rubber when they captured Indochina early in World War II. The idea of Vietnam as a front-line state was meaningless until American leaders made Vietnam a front-line state. The front-line concept was integral to Containment in that policy's generalization from Europe. Today we have a working arrangement with China and we know that the assumption that communism was an homogenous force was incorrecteven during the 1940's and 1950's as regards Ho Chi Minh's relations with China and the Soviet Union.

South Vietnam was not a democratic state and therefore could not be a test of Western democracy vs Soviet communism. Therefore the general significance of Vietnam in the global ideological competition between the two superpowers was questionable until it was made a signifcant issue through the American invasion. Today quite a few self-styled "Marxist-Leninist" regimes exist in the Third World and individually the United States attaches little strategic significance tot hem. That is as it should be. Cumulatively there may come a day when the United States finds itself in a hostile world but the popularity of Marxism in the Third World rides on the vehicle of reaction to perceived neocolonialism and is a force fragmented by tribal, national, and ideological schisms. Aside from the reaction of traditional peasants-described below-the American involvement in Vietnam was perceived by Third World elites within and without Vietnam as an attempt to exert dominion not an attempt to preserve the Free World against outside aggression. The more the United States became involved in Vietnam the more Marxism prospered globally and locally.

There are solid strategic reasons for the Soviets being in Afghanistan in contrast to the lack of such reasons for the United States to have been in Vietnam. The destabilization of Iran and Pakistan, the possibilities for interdiction of Western trade routes and oil resources, position for a warm water port, and intimidation of Turkey and India. Afghanistan is a linch pin for what could turn into a sudden-and vast-expansion of the Soviet empire. 
The Soviets did not even have to think in expansionist terms. Going into Afghanistan made very good sense in terms of shoring up the shakey status quo of their empire. The Afghan government was an endangered Marxist regime on the Soviet border. If the Brezhnev Doctrine did not apply in Afghanistan it might encourage the Poles or someone else to once more test its application to Eastern Europe. In addition a victory for an Islamic jihad over Marxism would be a serious disadvantage to the Soviets in their dealings with their Middle East clients-and also in terms of domestic control in Central Asia where the birth rate of the Moslem population outstrips that of Russian tirth and immigration rates. ${ }^{13}$ There were no comparable grounds that made good strategic sense for the United States to go into Vietnam-American officials only thought there were. If any war is right to fight and an objective comparison is made of the invasions of Vietnam and Afghanistan, Vietnam was a "wrong" war and Afghanistan was a "better" decision-although the verdict on Afghanistan is still out.

Vietnam was a failure of the American military as well as being a failure of the politicians ${ }^{14}$ The Americans had overwhelming military superiority over their enemy. They had no supply problems. Yet the military was defeated and that defeat is due to a failure to understand the nature of the war. Military organization and tactics were appropriate to a battlefield in Central Europe not the jungles and guerrilla warfare of Indochina. Morale was terrible and corruption widespread. ${ }^{15}$

The "search and destroy mission" was the primary tactic that American forces used on the ground in Vietnam.

${ }^{13}$ S.I. Bruk, "Ethnodemographic Processes in the USSR," The Soviet Review, Fall 1972; Robert A. Lewis, Richard H. Rowland, and Ralph S. Clem, Netionality and Population Change in Russia and the USSR (New York: Praeger, 1976).

14 This subject is well-treated and documented in Cecil B. Currey, Self-Destruction (New York: W.W. Norton, 1981) Military Book Club edition.

15 ibid, pp. 55-56. 
It was a policy of attrition that momentarily cleared swaths of territory only to allow that territory to fall back into enemy hands once American troops departed. The tactic did not even serve well the goal of attrition because body counts could not be accurately confirmed. General Westmoreland's lack of tactical imagination was so acute that the only alternative that he could pose to a war of attrition was a war of annihilation. ${ }^{16}$

Morale suffered from an attempt to make the boys feel like they were at home while they fought the war. The attempt did not make a hitch in Vietnam like playing cowboys and Indians back home the park on a Saturday afternoon. Instead the atempt disoriented the fighting men, contributed to their alienation from Vietnamese, and mushroomed the army bureaucracy and support staff. In 1968 at the zenith of American troop commitment the United Stated had 543,000 troops in Vietnam but only 80,000 of them-14\%-were combat troops! $!^{17}$ In 1971 the U.S. Army assigned approximately 3,285 soldiers for support activities for every 1,000 men int he field. This American practice compares with the current Soviet practice of assigning 580 support personnel per 1,000 combat personnel. ${ }^{18}$ Nobody will ever be able to validly depict the surrealism of Soviet involvement in Afghanistan as Francis Ford Coppola did of the American involvement in Vietna $\mathrm{m}$ with the USO troupe scene in Apocalypse Now. Playboy bunnies in the middle of the jungle did not stretch the truth too far.

The point is that the $14 \%$ of American soldiers who fought the war were demoralized by the large number of their fellow "soldiers" who sat through the war with soft jobs and who often got rich from dealing on the black market. Base camps were bee hives of officers and enlisted men in staff jobs and service/support activities who were never in danger of being sent into combat despite the fact that they were on active duty in a "war zone."

16 Norman Hannah, "Vietnam: Now We Know," National Review, June 11, 1976, p. 613.

17 Currey, Self-Destruction, p. 147.

18 Ronald J. Brown, Armor, November-December, 1976, p. 6. 
The Soviets may have learned from American mistakes. In Afghanistan they appear to be employing their own version of the enclave theory. Their troop levels have not greatly expanded: 85,000 at the time of invasion to an estimated 100,000 today. ${ }^{19}$ Approximately, 42,000-42\%-are combat troops who are based in heavily fortified garrisons and place the Soviets in strategic control of main urban areas and communication facilities. A mujahedeen commander once boasted to a German journalist that the Soviets "come with weapons as though they had to fight against the United States." ${ }^{20} \mathrm{He}$ and his troops fought back with 80-year old Enfields, homemade weapons, and captured equipment. The image conveyed by the commander's boast was not unlike the image of the United States playing a Central European gameplan in the jungles of Indochina. But the parallel is not entirely correct because the Soviets quickly tried to adapt the use of their equipment and firepower to the stringent requirements of Afghan terrain. Tanks are no longer taken into the mountains but remain in use on the plains where they can be effective. Hind helicopters give the Soviets increasing mobility in ferrying assault troops and dropping bombs and chemical weapons. There are reports that the Soviets have begun to reorganize their command structure in Afghanis$\tan$ around the imperatives of the peculiar style of warfare in the country. ${ }^{21}$

Unlike the United States in Vietnam the Soviets are not hindered by the constraints of a free-society. Media reports, individual consciences, and pluralist domestic politics do not prevent them from employing tactics that would bring domestic wrath down on a Western regime-policies of annihilation and population relocation. In this respect they take General Westmoreland at his word

19 The statistics are in "Afghanistan : 18 Months of Occupation," U.S. State Department Report No. 86, August 1981, p. 2; also in Stevens, "Whose Side is Time on This Time?" p. E2. p. 28.

${ }^{20}$ Klaus Imbeck, "With Allah on Our Side," Geo, December 1980,

2: "Old Bear in an Old Trap," The Economist, May 8, 1982, p. 68 
about the alternative to a war of attrition. The Soviet army makes heavy reprisals far in magnitude from guerrilla offenses. ${ }^{22}$ Relying on what worked in the subjugation of Moslem insurgents back in the 1920's and 1930's in Soviet Central Asia the Kremlin today combines outright annihilation of the population with enclave tactics. The vast outflow of refugees is also a plus in that it destabilizes Pakistan and creates social and political burdens in the area. $^{23}$ Making refugees of much of the population and compelling their flight to Pakistan not only destabilizes that country but removes many hostiles from practical opposition to the Soviet occupation. In effect the creation of refugees is population relocation-a policy that the Soviets have always followed with populations who are not susceptible to embracing Soviet rule. For the Soviets population relocation is not an attempt to win hearts and minds as was the misguided strategic hamlet program for the Americans in Vietnam. Instead it is an attempt to get rid of hearts and minds that will in a million years beco. me good Marxists. Those who are left behind by such a policy have their options severely curtailed and their children will be socialized into the correct beliefs.

The Americans were always looking for a "light at the end of the tunnel" in Vietnam. A succesful conclusion to the was in Afghanistan in the near future would no doubt please the Kremlin but the current situation is bearable for a much longer term than was true for the United States in Vietnam. As one diplomatic source is reported to have commented, "they apparently think that if they hold onto what they have now time is on their side." ${ }^{24}$

IV.

Once the troops arrived-both in Afghanistan and Vietnam-their effectiveness was limited by the failure of their

22 ibid, p. 71.

23 "Leaving Their Yaks Behind Them," The Economist, August 14, 1982 , p. 31.

${ }^{24}$ Stevens, "Whose Side is Time on This Time?" p. E2. 
civilian and military commanders to comprehend the nature of the local political cultures in which they sought to do battle for hearts and minds. The societies of Vietnam and Afghanistan are variations of traditional political culture. ${ }^{25}$ Major traditional characteristics that blunted American and Soviet policies are:

(1) A cyclical concept of history, antithetical to one of linear progression, and inclusive of the idea of the mandate of heaven;

(2) The incidental nature of psychological affinity in sharp contrast to the importance of ritual, ceremony, and economic relationships;

(3) The supremacy of particular loyalities to family, clan, village, or region over loyalty to national politicians and cəntral governments.

Frances Fitzgerald did the definitive examination of the American misunderstanding of traditional Vietnamese culture. The insights of her analysis in Fire in the Lake are useful for comparison with the Soviet involvement in Afghanistan. The Americans were tarred and feathered with allies in Vietnam who-demonstrably-reeked of corruption and could not maintain harmony within society. The French had earlier lost the mandate of heaven. First, they lost it to the Japanese and then, in attempting to regain control of Indochina, met disgrace at the hands of those who had taken the mandate from the Japanese, the Vietminh. The Americans, having aided in the ill-fated French effort and being physically similar to them, were ill suited for easy differentiation from the French-a fact that communist propaganda skillfully exploited. Tactics such as the strategic hamlet program, free-fire zones, and search and destroy missions did little to convince the averge Vietnamese that Americans or the clique of French-

${ }^{25}$ Three good sources for analyses of traditional culture (among many) are: C.W. Cassinelli and Robert B. Ekvall, A Tibetan Principality: The Political System of Sa sKya (Ithaca: Cornell, 1969); Frances Fitzgerald, Fire in the Lake (New York: Vintage Paperback, 1972); Laurence Wylie. Villaze in the Vaucluse (Cambridge: Harvard, 1974, 3rd ed.). 
trained South Vietnamese officers in Saigon could claim the mandate of heaven. General Westmoreland conceived of body counts as measuring progress towards victory in a war of attrition. Vietnamese peasants reacted to the slaughter as evidence that the current historical cycle was in its recurrent phase of revolution. Americans designed pacification programs and elections in part to "progress" Vietnamese out of the ignorance of their supposed backward society. Vietnamese reacted with repugnance and in revolt-a traditional reaction to overbearing rulers who could neither maintain the observance of custom by others nor obey it themselves. The NLF and North Vietnamese compared favorably with the Americans and Saigon regime because they built a sense of community within the areas that they occupied in which-as in traditional society-everyone had their place. The NLF and North Vietnamese maintained discipline within what they built. Meanwhile the Americans created increasing chaos.

The Soviet Union invaded Afghanistan after the Khalq regimes of Taraki and Amin had so offended traditional harmony that revolt occurred. Prior to the April 1978 coup Prime Minister Daoud led a government that-from time to time-proclaimed reforms that would have thrown the country into chaos had they been implemented. ${ }^{26}$ The key to Daoud's ability to maintain a semblance of harmony within traditional Afghanistan was that the proclaimed reforms were only given lip service by his government.

After the 1978 coup the new Khalq regime set about performing a revolution. After triumphing over the Parcham faction it implemented reforms which, in the autumn of 1978, resulted in revolt in the countryside that grew to be a serious problem. Khalq wanted to push hard to mobilize the countryside behind the new Marxist ideology. Mobilize the countryside Khalq did but hardly in the "progressive" way that leaders in Kabul had envisioned.

The regime perceived itself in the role of ending an exploitative society wherein land-rich leaders and families

\footnotetext{
26 Arnold, Afghanistan : the Soviet Invasion, p. 33, p. 61.
} 
exploited the masses of rural poor and tenant farmers. This Marxist perception was far from reality. In Afghanistan most people accepted and gave loyalty to the traditional order. ${ }^{27}$ Secular and religious leaders in the countrysido had long been successfully preserving harmony in the observance of custom and had presided over land-tenure that resulted in viable agricultural production.

The immediate result of Khalq land reform was a one-third drop in the wheat harvest. ${ }^{28}$ People who knew that their holdings were going to be expropriated did not plant fields that they presumed would be taken from them. Other people were reluctant to accept land from the regime because Islam taught against taking someone else's property. Harmony and custom were further disrupted by the regime's attempts to undercut traditional leaders. In traditional logic the people were justified in resisting uhe Khalq regime and finding leaders who could restore harmony.

The Soviets had warned Khalq about counterrevolutionary reaction to fast-paced reforms and Parcham, on the basis of cadre experience, sided with the Soviets. ${ }^{29}$ When the Soviets intervened in an attempt to salvage a Marxist regime out of the chaos hat Khalq had created they were unavoidably tarred with the loss of the mandate of heaven. The very fact that their invasion did not end the revolt but instead contributed to wider and more disruptipve chaos only confirmed traditional logic for the average Afghan.

The very concept of winning "hearts and minds" or worrying about ideological purity and social progress is alien to traditional peoples. Outward behavior is significant not the mental processes and emotions within. Elaborate rituals, custom, and economic relationships combine to constrain the unpredictable expression of attitudes and emotion therefore making human behavior predictable and society harmonious. An infidel taken captive by Moslem warriors in the days of Captain John Smith could save the

${ }^{27}$ Nancy Peabody Newell and Richard S. Newell, The Struggle for Afghanistan (Ithaca: Cornell, 1981), pp. 80-81.

${ }_{23}$ ibid, p. 81.

${ }^{29}$ Arnold, Afghanistan : the Soviet Invasion, pp. 77-79. 
rest of his skin merely by agreeing to the removal of his foreskin. Circumcision signified conversion to Islam and that was important-not the feelings of the "former" infidel who may have secretly harbored his old beliefs. In Vietnam the United States attempted to impose on traditional peasants a system of government that was predicated on individual responsibility and attitudes. As Fitzgerald points out the vote was an "instrument of terror"30 for the average Vietnamese. It placed the peasant outside of custom-it was not his place to be running things.

The NLF did not predicate its policies on individual responsibility. Instead it concentrated on giving villagers a place within their group. Communist collectivism was more compatible in Vietnam with traditional individualism than was bourgeois individualism. The traditional indivdual says, "leave me alone n my place;" the bourgeois individual says "respect me for my merit and reasoned opinions."

In Vietnam even before the Americans arrived traditional Vietnamese society had been corrupted and dislocated by French colonial influence. In Afghanistan the Khalq regime inherited an intact traditional society. In Vietnam the communists built their new society by adapting traditional forms to their own uses. In Afghanistan the communists deliberately put themselves in the role that the French had inadvertantly filled in Vietnam-they set out to destory traditional society.

An important part of the Khalq reform was new family law. The requirement of a marriage license took away the power of heads of families to authorize marriages. The reduction of the bride price from $\$ 1000$ to $\$ 6$ created severe economic dislocation within the traditional family. ${ }^{32}$ The bride price had functioned to compensate the bride's family for the loss of her dowry and for the loss of her work within the family unit. The Khalq reduction of the bride price transformed unmarried women into economic liabi-

${ }^{30}$ Fitzgerald, Fire in the Lake, pp. 440-441.

31 C.W. Cassinelli in lectures on the subject at the University of Washington.

32 Newell and Newell, The Struggle for Afghanistan, pp. 82-83. 
lities who no longer had incentive to obey the traditional authority of family heads. Moreover these women were robbed of stability. As economic liabilities they lost their place within family units that owed their cohesiveness to economic roles.

In Vietnam the peasants suffered the presence of central government officials with no enthusiasm. Most officials had no roots in the villages and saw their positions only as an opportunity to mark time with graft before they could make it back to the city. Even those officials who arrived with some integrity cut through local patterns of traditional authority when they administered Saigon's decrees and by doing so they usurped responsibility : all ills could thereafter be laid at their door and, by extension, Saigon's. The interdiction of traditional loyalties had an effect opposite that of consolidating Saigon's hold on the countryside.

In Afghanistan the Khalq regime experienced similar consequences to its policies for consolidating control outside Kabul. A particularly illustrative example, described by: the Newells, ${ }^{33}$ is the rebellion of the Nuristani tribe. Prior to 1978 the Nuristanis coexisted with Kabul by means of an arrangement giving the tribe internal autonomy. Nuristani khans regulated and maintained harmony within the tribe's domains and acted as contacts with Kabul's representatives to a greater extent than was true of other tribal leaders within Afghanistan. This arrangement had evolved because of the hostility of the Nuristanis towards the dominant Pushtuns and because their home territory was strategically located on the border with British India (later Pakistan). In addition to the liasion roles of the khans several Nuristanis were always present in the Afghan officer corps at a senior level. These Nuristani officers provided the government insurance that Nuristani territory would remain loyal and, at the same time, they provided the Nuristanis with the assurance that whatever regime was in Kabul would "rule" the Nuristanis only through the interface of the khans.

33 ibid, pp. 99-103. 
The Khalq leaders upset the long-adhered to status quo with the Nuristanis. First they executed most of the Nuritan military officers ostensibly because that had supported the Daoud regime. Second they arrested the khans in order to break their leadership and to provide for the direct administration of the Nuristanis from Kabul. When emissaries of direct administration were sent into Nuristani country the Nuristanis treated them like the Lakota Soux treated General Custer. By early autumn 1978 the Nuristanis had government troops pinned down and had fortified themselves in the rugged mountains of their homeland.

The Khalq attempt to make of the Nuristanis an example backfired disastrously. The government only demonstrated its weakness and facilitated the revolt of other ethnic groups as those other groups came to feel the full bite of Khalq policies. Ethnic group after ethnic group revolted in the Nuristani pattern until, at the end of 1978 , all sections of the Afghan population were in revolt against the Marxists.

The foregoing comparison shows that the policies of the invaders were counterproductive to their goals. The Americans only slowly became aware of the problem of cultural mismeshing and that gradual awareness never permeated through to the main decision makers. The kind of analysis done by Fitzgerald should have been performed at the outset of the American involvement. The various "fact-finding" trips of Secretary of State Robert MacNamara, Vice President Johnson, and others were poor substitutes. The Soviets were more aware from the beginning, as is demonstrated by their warnings to Khalq, of the dangerous reaction that fullspeed reforms were likely to ignite. In the end the choice of invasion was made because of the reaction to Khalq reforms and the Soviets have put themselves in the position in which the United States put itself in Vietnam. A major contrast exists between the two invasions in that the Soviets appear to have made policy changes to adapt strategy and tactics to the imperatives of terrain and cultural mismeshing. 
V.

The Soviets may have put themselves in alliance with those in Afghanistan who lost the mandate of heaven but that does not mean that Afghanistan has become "Russia's Vietnam" in the sense that they will experience defeat as the United States experience defeat as the United States experienced defeat. Built into the Soviet framework of rationality is their concept of who destroys whom?-the correlation of forces. ${ }^{34}$ The correlation of forces requires Soviet leaders as a matter of "scientific" Marxist analysis to attempt discriminating judgements about the consequences of their policies and to err on the side of being prudent. Contrast the correlation of forces with the "can do" attitudes and projections based on faulty statistics that kept American officials looking for the light at the end of the tunnel in Vietnam.

The concept of the correlation of forces is one reason why the Soviet warned Khalq against swiftly implementing reforms and then later sought to single out Hafizullah Amin as a scapegoat for everything that had gone wrong in Afghanistan since the 1978 coup. Unfortunately for the Soviets they were not able to portray themselves as having taken the mandate away from Amin because Amin had long been perceived by the mujahedeen to have lost it. The Soviets have not attempted to transport their home society and its trappings to Afghanistan so that the boys can come back from a day fighing the guerrillas to the disorientation of home away from home. They do not have an outrageous percentage of support personnel in ratio to their combat forces committed in Afghanistan. They have learned from the American experience in Vietnam and appear to be making an effort to minimize their visibility in Afghanistan-difficult as that may be given the circumstances of war.

Part of the attempt to minimize Soviet visibility involves the fashioning of a nationalities policy that, in the short

34 Nathan Leites, A Study of Bolshevism (Glencoe: Free Press, 1953), p. 28; Lenczowski, Soviet Perceptions, pp. 51-59. 
cerm, is designed to accentuate tribal divisions within traditional Afghanistan and, in the long run, provide the political form by which Marxist rule can subsume traditional society. The nationalities policy is, of course, patterned on their experience in Soviet Central Asia where each of the different ethnic groups have their own republic.

Just as party leaders are the "vanguard" of the Russian people so too the Kremlin leaders conceive of the Russian people as the vanguard people within the Soviet Union. In Central Asia the cities are the vortexes of change because institutions of administration, higher education, and industry are located within them. The major urban presence within Central Asia is Russian. ${ }^{35}$

Communist party leadership within the indigenous republics usually requires that the First Secretary, a national, be checked by his Russian comrade, the second secretary. ${ }^{36}$ The First Secretary will have reached that position only after education in a Russian institution and after training in party schools. The form of a national republic with its substance controlled within the USSR by tight administrative control from the Kremlin is a model attractve to Middle Eastern states with their own nationality problems. The Soviet administration holds out the promise of keeping the dominant ethnic groups in control while at the same time defusing conflicts over autonomy and eventually welding the entire population into a single "Iraqi" or "Syrian" nationality.

Historically the dominant ethnic group in Afghanistan has been the Pushtuns. The Pushtuns have controlled access to public office, made languages official, owned the best grazing lands, etc. Within traditional Afghanistan the tribe is the highest form of poltical loyalty that has any real substance and rivalry between the tribes means a weak

35 Lewis, Rowland, and Clem, Nationality and Population Change, pp. 146-147; "Ethnic Groups: Demography Language," Current Digest of the Soviet Press, vol. xxvi, no. 42, p. 11.

36 John H. Miller, "Cadres in Nationality Areas: Recruitment of CPSU First and Second Secretaries in Nion-Russian Repubilics of the USSR," Soviet Studies, January 1977, pp. 3-6, 19-20. 
sense of Afghan nationalism. Except for the Pushtuns all of the tribes within Afghanistan can be found within Soviet Central Asia in significant numbers. Tribal terrtores not only overlap between Afghanstan and Soviet Central Asia but also between Afghanistan and Iran and Afghanistan and Pakistan. A successful nationality policy implemented in Afghanistan by the Marxist would be a strong basis for provoking turmoil in Iran and Pakistan against the central governments in Tehran and Islamabad.

A successful nationality policy in Afghanistan would also help to legitimize further Soviet military action beyond Afghan borders. Currently the perception of the Soviet invasion by the Central Asian ethnic groups as intended to liberate their oppressed relatives in Afghanistan has gone a long way towards defusing any reaction against the invasion based on Islamic culture. The same image could be generated later with respect to invasions of Iran and Pakistan. ${ }^{37}$

By early 1982 the Soviets could not be said to have successfully employed their nationality policy in Afghanistan because success will come only if it helps them win the war. But one report from Peshawar, Pakistan, concluded that "the Russians are buying themselves relative peace in some areas." "Se "Settled" (as opposed to "nomadic" peoples-among whom Kabul now includes refugees) tribes hav $\theta$ had their languages made official and their unique cultures ballyhooed. The Afghan Ministry of Tribes now deals with tribal pathans much like the Nuristani khans used to be dealt with and brotherhood is stressed with national cousins across the border in the Soviet Union. Within the Ministry there is a section, the Akhwan, which has the mission of provoking tribal frictions among peoples inha-

37 For a recent journalist's interview with Sovict Central Asians on their perceptions of the war-which tend to bear out the legitimizing power of Soviet nationality policy for current and future operations-see Newsweek, August 9, 1982, p. 36. For a scholar's analysis read Naby, "The Ethnic Factor in Soviet-Afghan Relations," p. 241.

38 "Accept Us and You Won't Regret It," The Economist, February 27, 1982, p. 54 . 
biting the border area with Pakistan in order to inhibit guerrilla activities and infiltration from Pakistan. ${ }^{39}$

Soviet nationality policy is a culturally appropriate strategy for the war in Afghanistan. In contrast to Vietnam, where traditional authority had been eroded by French influence, patterns of traditional authority are strong in Afghanistan. In fact, traditional leaders, including heads of families, have become guerrilla commanders. ${ }^{40}$ Any Soviet policy which accentuates traditional divisions and patterns will help to inhibit the formation of Afghan nationalism and will undercut efforts by mujahedeen leaders in Pakistan and elsewhere to set up an effective central coordinating body for the resistance. In contrast to the Americans in Vietnam the Soviets have come to grips with the major military prcblem of a political war: "how to adapt, quickly and successfully, to the peculiar and unfamiliar battlefield conditions." nam and Afghanistan the battlefield spans relations with the indigenous society.

A successful Soviet conclusion to the war in Afghanis$\tan$ will demonstrate to skeptics in the West that military force is still a potent tool for superpower use. Those who have drawn a contrary lesson from the American defeat in Vietnam overlook the fact that the communist victory in Vietnam came through the use of military force. The important point that has been lost sight of is that military force does not exist nor is it used in a vacuum.

VI.

We are fortunate that since World War II the competition between the United States and the Soviet Union has resulted in a global balance of power. Unfortunately, given the right circumstances, there is no logical reason why

\footnotetext{
39 "As Stalin Said...," The Economist, March 13, 1982, p. 58.

40 Newell and Newell. The Struggle for Afghanistan, p. 91.

${ }^{41}$ Stephen P. Rosen, "Vietnam and the American Theory of Limited War," International Security, Fall 1982, p. 83.
} 
there can not also result the unwanted byproduct of global imbalance-especially an imbalance short of nuclear war. Such an imbalance could vary in character from the des. tabilization of several different regions around the globe simultaneously to eventual cultural, economic, and political isolation of the United States. Picture an America whose government had allowed it to fall in the same "encircled" position that Stalin perceived the Soviet Union to be in: there would result such political shock that no one could be safe in prediciting the catastrophic consequences over a wide variety of spheres. Such catastrophe need not be political science fiction-the possibility is underscored in the foregoing comparison of American and Soviet performances and it is clear that the United States must do a better job of competing with the Soviet Union. A failure to compete adequately will generate global imbalance; in a word, catastrophe.

Global imbalance will threaten the preservation of our independence and our systems of values throughout the West. It is within our systems that we can argue that war is immoral and strive to get those who have other value systems to agree with us. Ironically we have a tendency in the West to liberally accord the benefit of the doubt even to those who, such as Lenin or Hitler, explicitly repeat that their intention is to destroy us. When our value systems are taken over by such dedicated people they no longer need the benefit of the doubt previously accorded to them and we can no longer argue with them. We have not reached that point with the Soviet Union but the danger looms. The Soviet invasion of Afghanistan did not immediately threaten the global power balance but if the Soviets emerge victorious there-in a a victory any way comparable to their victory of the 1920's in Central Asia-global imbalance is more probable that improbable.

If the Soviets succeed in Afghanistan the significance of their victory will not be confined to the fact that, unlike the United States in Vietnam, they were able to employ enough brute force and to design their policies to blandish the sensibilities of a traditional people. The significance 
will be in terms of the world's perceptions of the relative power of the United States and the Soviet Union-including policy makers in Washington and Moscow.

A world-wide perception that the Soviet Union can do what the United States cannot will be a systems-wide characteristic of the international environment. Such a perception will have an effect on the distribution of power capabilities across the international system and weight the balance more heavily in favor of the Soviet Union than it is now alleged to be by some of the alarmists in our midst. Actual military power ratios will have little to do with such an effect-it is the intangible component of psychological ratios-perceptions-that will be crucial.

The United States should not wait to see what lesson the world is going to draw from a Soviet victory in Afghanistan. It should do its best to make the Soviet involvement there as costly as possible by seeing to it that the mujahedeen get all the supplies that they need to sustain their resistance and all the outside publicity and political access that they need to wage a successful propaganda war in media organs and the United Nations.

The longer the Soviets wallow in Afghanistan the greater will be their costs both internally and externally. If they withdraw they will not leave behind a vacuum filled by American troops but if they win they will have come much closer to their long term goal of dominating the international system. It does not threaten the stability of the world to exact costs from the Soviets in Afghanistanquite the reverse. But it is vital that we sustain the mujahedeen in their own fight for their own way of life. If Western policy makers assume that the mujahedeen are fightig for liberal Wester values any "help" extended to the mujahedeen may very well end up being counterpro. ductive. It is their fight but it is within our interests to buttress it. 